\title{
Model Analisis Solvabilitas, Aktifitas dan Profitabilitas Terhadap Nilai Pasar Saham dengan Share Traded sebagai Variabel Intervening pada Perusahaan Sub Sektor Food And Baverages di Bursa Efek Indonesia Periode 2014 - 2019
}

\author{
Siti Nur Ambarini*, Yunan Surono \\ Magister Manajemen Universitas Batanghari \\ *Correspondence email: yunansurono@yahoo.com
}

\begin{abstract}
Penelitian ini untuk melihat kinerja perusahaan food and baverages, dengan melihat hubungan antara variabel solvabilitas, aktifitas, dan profitabilitas terhadap nilai pasar saham dengan share traded sebagai variabel intervening pada sub sektor food and baverages yang ada di Bursa Efek Indonesia selama periode 2014-2019. Penelitian ini menggunakan variabel bebas pertama yakni variabel solvabilitas yang diproksikan dengan indikator debt to asset ratio dan debt to equity ratio. Penelitian ini menggunakan variabel bebas kedua yakni variabel aktifitas yang diproksikan dengan total asset turnover, fixed asset turnover dan inventory turnover. Variabel bebas ketiga yakni variabel profitabilitas yang diproksikan dengan indikator return on asset, return on equity, net profit margin dan gross profit margin. Variabel terikat yakni variabel nilai pasar saham yang diproksikan dengan indikator price earning ratio, price book value, dan earning per share. Variabel intervening yakni share traded dengan indikator volume traded, value traded, frequency traded dan days traded. Sampel penelitian yang digunakan adalah kelompok saham sub sektor food and baverages selama 6 tahun periode pengamatan, dimulai dari tahun 2014 - 2019, yang memiliki laporan keuangan dengan indikator penelitian yang lengkap, laporan keuangan dengan menggunakan nilai mata uang rupiah yakni sebanyak 16 emiten. Penelitian ini berupa penelitian eksplanatoris (explanatory research) dan analisis data menggunakan Partial Least Square dengan menggunakan software Smart PLS 3.0 Hasil penelitian menunjukkan, variabel solvabilitas tidak berpengaruh terhadap share traded, variabel aktifitas berpengaruh terhadap share traded, variabel profitabilitas tidak berpengaruh terhadap share traded, variabel solvabilitas tidak berpengaruh terhadap nilai pasar saham, variabel aktifitas tidak berpengaruh terhadap nilai pasar saham, variabel profitabilitas berpengaruh terhadap nilai pasar saham, variabel solvabilitas tidak berpengaruh terhadap nilai pasar saham, variabel aktifitas tidak berpengaruh terhadap nilai pasar saham dengan share traded sebagai variabel intervening, variabel profitabilitas tidak berpengaruh terhadap nilai pasar saham dengan share traded sebagai variabel intervening, variabel share traded tidak berpengaruh terhadap nilai pasar saham.
\end{abstract}

Kata Kunci: Solvabilitas, Aktifitas dan Profitabilitas, Nilai Pasar Saham, Share Traded, Variabel Intervening

Abstract. This study is to look at the performance of food and baverages companies, by looking at the relationship between solvency variables, activities, and profitability to the stock market value with share traded as intervening variables in the food and baverages sub-sector on the Indonesia Stock Exchange during the period 2014-2019. This study uses the first free variable which is a solvency variable that is projected with debt to asset ratio indicator and debt to equity ratio. This study uses the second free variable which is the activity variable that is projected with total asset turnover, fixed asset turnover and inventory turnover. The third free variable is the profitability variable that is projected with indicators of return on asset, return on equity, net profit margin and gross profit margin. Bound variables are variable stock market value that is projected with price earning ratio indicator, price book value, and earning per share. Intervening variable is share traded with indicator volume traded, value traded, frequency traded and days traded. The research sample used is a group of food and baverages sub-sector stocks during the 6-year observation period, starting from 2014 - 2019, which has financial statements with complete research indicators, financial statements using the value of rupiah currency, namely as many as 16 issuers. This research is in the form of explanatory research and data analysis using Partial Least Square using Smart PLS 3.0 software The results show, solvency variables have no effect on share traded, activity variables affect share traded, profitability variables have no effect on share traded, solvency variables have no effect on stock market value, activity variables have no effect on stock market value, profitability variables affect stock market value, solvency variables have no effect on the value of the stock market, activity variables have no effect on the value of the stock market with share traded as intervening variables, profitability variables have no effect on the value of the stock market with share traded as intervening variables, share traded variables have no effect on the value of the stock market.

Keywords: Solvency, Activity and Profitability, Stock Market Value, Share Traded, Intervening Variables

\section{Pendahuluan}

Indonesia sebagai pasar yang besar bagi hasil produk makanan dan minuman yang dihasilkan oleh perusahaan emiten sub sektor food and baverages yang ada di Bursa Efek Indonesia. Kondisi ekonomi makro yang selalu berubah-ubah baik yang bersumber dari dalam dan luar negeri, serta faktor kinerja dari masing-masing sektor industri yang berbeda-beda, dan kinerja perusahaan emiten yang berbeda-beda dengan perbedaan yang cukup signifikan, akan mempengaruhi besarnya penjualan, laba, dan tingkat keuntungan yang diperoleh bagi investor. Kinerja perusahaan sub 
Siti Nur Ambarini dan Yunan Surono, Model Analisis Solvabilitas, Aktifitas dan Profitabilitas Terhadap Nilai Pasar Saham dengan Share Traded sebagai Variabel Intervening pada Perusahaan Sub Sektor Food And Baverages di Bursa Efek Indonesia Periode 2014 - 2019

sektor food and baverages yang ada di Bursa Efek Indonesia pada umumnya cukup baik pada kuartal 12020 karena seluruh sektor mencatatkan kinerja negatif, dan sektor food and baverages yang paling minim mengalami tekanan. (market.bisnis.com). Ketua Ketua Umum Asosiasi Gabungan Pengusaha Makanan Minuman Indonesia (GAPMMI), Adhi S. Lukman, memprediksikan industri Food and Beverage (F\&B) di 2021 bisa tumbuh mencapai 5-7 persen. Industri food and baverage mengalami keterpurukan akibat pandemi covid-19, hal tersebut sudah terlihat dari realisasi pertumbuhan ekonomi di kuartal II 2020 yang minus 5,32 persen.(liputan6.com.).

Penelitian ini akan menggunakan variabel bebas pertama (X1) berdasarkan kinerja perusahaan berupa variabel solvabilitas (leverage) yang diproksikan dengan Debt to Asset Ratio (DAR) dan Debt to Equity Ratio (DER). Kinerja perusahaan salah satunya dapat tergambar melalui solvabilitas perusahaan. Solvabilitas akan mempengaruhi besarnya nilai pasar saham suatu perusahaan yang disebabkan oleh adanya peluang investasi yang dipertimbangkan para investor melalui laporan keuangan emiten termasuk besaran hutang jangka panjang (leverage). Perusahaan yang memiliki solvabilitas yang baik cenderung mempunyai citra yang baik di mata pasar karena pasar akan menganggap bahwa perusahaan itu mampu untuk melunasi kewajiban jangka pendek dan jangka panjangnya, sehingga dianggap dapat terhindar dari risiko kebangkrutan. Penelitian ini juga akan menggunakan variabel bebas kedua (X2) berdasarkan kinerja perusahaan berupa variabel aktifitas yang diproksikan dengan perputaran total aktiva (Total Asset Turnover/ TATO), perputaran total aktiva tetap (Fixed Asset Turnover/ FATO) dan perputaran persediaan (Inventory Turnover/ ITO), aktifitas perusahaan dalam menjalankan operasinya tentu akan mempengaruhi kemampuan perusahaan emiten untuk memperoleh laba operasinya, sehingga akan berpengaruh terhadap harga saham di mata investor dan pasar secara umum dan akan mempengaruhi minat investor terhadap saham perusahaan tersebut di pasar.

Penelitian ini juga akan menggunakan variabel bebas ke tiga berdasarkan kinerja perusahaan berupa profitabilitas, variabel profitabilitas yang diproksikan dengan tingkat pengembalian aset (Return On Asset / ROA), tingkat pengembalian modal (Return On Equity / ROE), margin laba bersih (Net Profit Margin / NPM) dan margin laba kotor (Gross Profit Margin / GPM). Perusahaan yang memiliki profitabilitas tinggi cenderung mempunyai nilai perusahaan yang tinggi pula karena jika laba yang diperoleh perusahaan tinggi, maka pasar juga akan memiliki perspektif yang baik pula terhadap perusahaan tersebut sehingga dengan begitu perusahaan juga akan lebih bernilai bagi investor dan pasar, sehingga akan mampu mempengaruhi nilai pasar saham perusahaan emiten. Penelitian ini menggunakan variabel terikat (dependent) berupa nilai pasar saham (Y), yang diproksikan dengan dengan indikator price earning ratio (PER), price book value (PBV), dan earning per share (EPS) yang merupakan variabel yang dipengaruhi oleh kinerja perusahaan emiten dari variabel bebas berupa solvabilitas, aktifitas dan profitabilitas. Nilai pasar saham perusahaan emiten secara keseluruhan akan sangat terkait dengan besarnya investasi dan perdagangan saham emiten yang ada di Bursa Efek melalui variabel share traded

Peneliti menjadikan share traded sebagai variabel intervening (I) yang tergambar melalui volume perdagangan (volume traded), nilai perdagangan (value traded), frekuensi perdagangan (frequency traded) dan hari perdagangan (days traded), sehingga diharapkan mampu menjadi perantara dan sekaligus gambaran yang memadai bagi pengaruh kinerja perusahaan terhadap nilai pasar saham perusahaan terutama bagi para investor dan pasar secara umumnya. Investor yang cerdas cenderung mempertimbangkan beberapa aspek sebelum menanamankan modalnya guna menghindari kemungkinan terburuk termasuk kinerja perusahaan berdasarkan solvabilitas, aktifitas dan profitabilitas. Tujuan penelitian ini adalah menggunakan variabel solvabilitas, aktifitas, dan profitabilitas terhadap nilai pasar saham dengan share traded sebagai variabel intervening, dengan objek saham-saham perusahaan emiten sub sektor food and baverages yang ada di Bursa Efek Indonesia selama periode 2014-2019

\section{Kajian Teoritis}

Penelitian ini dilakukan pada perusahaan emiten sub sektor food and baverages yang ada di Bursa Efek Indonesia, guna melihat kinerja masing-masing perusahaan sekaligus melihat kinerja sektoralnya. Penelitian ini akan menggunakan variabel bebas pertama berdasarkan kinerja perusahaan berupa solvabilitas (leverage), variabel solvabilitas (leverage) yang diproksikan dengan Debt to Asset Ratio (DAR) dan Debt to Equity Ratio (DER), variabel aktifitas yang diproksikan dengan perputaran total aktiva (Total Asset Turnover/ TATO), perputaran total aktiva tetap (Fixed Asset Turnover) dan perputaran persediaan (Inventory Turnover). Variabel bebas ke tiga berdasarkan kinerja perusahaan berupa variabel profitabilitas yang diproksikan dengan tingkat pengembalian aset (Return On Asset), tingkat pengembalian modal (Return On Equity), margin laba bersih (Net Profit Margin) dan margin laba kotor (Gross Profit Margin) dan menggunakan variabel terikat berupa nilai pasar saham yang diproksikan dengan dengan indikator price earning ratio (PER), price book value (PBV), dan earning per share (EPS) serta variabel share traded sebagai variabel intervening yang tergambar melalui indikator volume perdagangan (volume traded), nilai perdagangan (value traded), frekuensi perdagangan (frequency traded) dan hari perdagangan (days traded).

Solvabilitas menggambarkan kemampuan perusahaan dalam membayar kewajiban jangka panjangnya atau kewajiban-kewajibannya apabila perusahaan dilikuidasi. Sudana (2011), mengemukakan bahwa solvabilitas mengukur 
Siti Nur Ambarini dan Yunan Surono, Model Analisis Solvabilitas, Aktifitas dan Profitabilitas Terhadap Nilai Pasar Saham dengan Share Traded sebagai Variabel Intervening pada Perusahaan Sub Sektor Food And Baverages di Bursa Efek Indonesia Periode 2014 - 2019

berapa besar penggunaan utang dalam pembelanjaan perusahaan. Kemampuan perusahaan dalam membayar hutangnya merupakan tanda atau signal bahwa manajemen mempunyai kinerja yang baik dalam menjalankan segala kegiatan operasional perusahaan ayang tergambar melalui DAR dan DER dimana nilainya semakin kecil akan semakin baik, dan akan mempengaruhi keputusan bagi investor untuk melakukan keputusan untuk melakukan transaksi perdagangan saham dipasar. Jika transaksi dilakukan secara rutin dan terus menerus dan dengan jumlah transaksi yang besar maka akan berdampak pada pergerakan harga saham dipasar. Perdagangan suatu saham yang aktif dengan volume, nilai dan frekuensi perdagangan yang besar, menunjukkan bahwa saham tersebut diminati oleh para investor yang berarti saham tersebut cepat diperdagangkan. Investor termotivasi untuk mendapatkan saham sebanyak mungkin dengan tujuan mendapat pembagian dividen berkala dan atau kekuatan voting pada dewan pemilik saham. Keaktifan perdagangan saham juga tergambar dari hari perdagangan merupakan bagian dari para pedagang maupun para spekulan melakukan jual beli saham pada hari yang sama sebelum perdagangan saham ditutup, dan biasanya bermotif pada mencari keuntungan. Dampak selanjutnya akan mempengaruhi nilai pasar saham perusahaan tersebut dipasar.

Sudana (2011), mengemukakan bahwa aktifitas perusahaan digunakan untuk mengukur efektivitas dan efisiensi dalam mengelola aktiva yang dimiliki perusahaan yang tergambar melalui indikator TATO, FATO dan ITO, jika angka yang dimilikinya semakin tinggi maka akan semakin baik. Jika tingkat efektivitasnya tinggi maka diharapkan perolehan laba perusahaan semakin besar, hal ini akan menujukkan kinerja perusahaan semakin baik. Kinerja perusahaan yang semakin baik memberikan dampak pada harga saham perusahaan tersebut akan semakin tinggi dan harga saham yang tinggi memberikan signal dan harapan bagi investor yang semakin besar, sehingga akan mempengaruhi nilai pasar saham dipasar. Perdagangan suatu saham yang aktif dengan volume, nilai, frekuensi dan hari perdagangan yang besar, menunjukkan bahwa saham tersebut diminati oleh para investor dan berdampak pada nilai pasar saham tersebut. Fahmi (2011) mengemukakan bahwa profitabilitas mengukur efektifitas manajemen secara keseluruhan yang ditunjukkan oleh besar kecilnya tingkat keuntungan yang diperoleh dalam hubungannya dengan penjualan maupun investasi. Jika tingkat profitablitasnya tinggi yang tergambar melalui besaran angka ROA, ROE, NPM dan GPM dimana hal ini menujukkan kinerja perusahaan yang baik. Kinerja perusahaan yang baik memberikan dampak pada harga saham perusahaan tersebut akan semakin tinggi dan harga saham yang tinggi memberikan signal dan harapan bagi investor yang semakin besar untuk melakukan transaksi perdagangan saham (share traded), sehingga akan mempengaruhi nilai pasar saham dipasar.

Variabel share traded dengan indikator volume perdagangan saham merupakan salah satu indikator yang digunakan dalam análisis teknikal pada penilaian harga saham dan suatu instrumen yang dapat digunakan untuk melihat reaksi pasar modal terhadap informasi melalui parameter pergerakan aktivitas volume perdagangan saham dipasar. Selain itu, variabel share traded dengan indikator trading value yang merupakan kegiatan jual atau beli saham untuk mendapatkan keuntungan dari selisih harga pembelian awal terhadap harga jual terakhir (capital gain). Pada investasi saham, investor termotivasi untuk mendapatkan saham sebanyak mungkin dengan tujuan mendapat pembagian dividen berkala dan atau kekuatan voting pada dewan pemilik saham. Dengan begitu investor akan mempertahankan holding-nya dalam jangka waktu relatif lama. Adapun pada trading saham, trader hanya termotivasi untuk mendapatkan keuntungan sebesar mungkin dari pergerakan harga saham dalam periode sesingkatsingkatnya. Silviyani (2014), saham yang memiliki frekuensi perdagangan besar diduga dipengaruhi transaksi saham yang sangat aktif, hal ini disebabkan karena banyaknya minat investor, dengan demikian dapat diketahui saham tersebut diminati investor atau tidak. Days trading merupakan bagian dari para pedagang maupun para spekulan melakukan jual beli saham pada hari yang sama sebelum perdagangan saham ditutup, dan biasanya bermotif pada mencari keuntungan. Days trading bertujuan untuk menghindari risiko yang tidak dapat dikelola maupun sebagai akibat kesenjangan harga negative antara harga penutupan satu hari dengan hari berikutnya.

\section{Hipotesis}

Hipotesis dalam penelitian ini antara lain sebagai berikut:

1. Diduga solvabilitas berpengaruh terhadap share traded pada perusahaan sub sektor food and baverages di Bursa Efek Indonesia periode 2014 - 2019.

2. Diduga aktifitas berpengaruh terhadap share traded pada perusahaan sub sektor food and baverages di Bursa Efek Indonesia periode 2014 - 2019.

3. Diduga profitabilitas berpengaruh terhadap share traded pada perusahaan sub sektor food and baverages di Bursa Efek Indonesia periode 2014 - 2019.

4. Diduga solvabilitas berpengaruh terhadap nilai pasar saham perusahaan sub sektor food and baverages di Bursa Efek Indonesia periode 2014 - 2019.

5. Diduga aktifitas berpengaruh terhadap nilai pasar saham perusahaan sub sektor food and baverages di Bursa Efek Indonesia periode 2014 - 2019. 
Siti Nur Ambarini dan Yunan Surono, Model Analisis Solvabilitas, Aktifitas dan Profitabilitas Terhadap Nilai Pasar Saham dengan Share Traded sebagai Variabel Intervening pada Perusahaan Sub Sektor Food And Baverages di Bursa Efek Indonesia Periode 2014 - 2019

6. Diduga profitabilitas berpengaruh terhadap nilai pasar saham perusahaan sub sektor food and baverages di Bursa Efek Indonesia periode 2014 - 2019.

7. Diduga solvabilitas berpengaruh terhadap nilai pasar saham dengan share traded sebagai variabel intervening pada perusahaan sub sektor food and baverages di Bursa Efek Indonesia periode 2014 - 2019.

8. Diduga aktifitas berpengaruh terhadap nilai pasar saham dengan share traded sebagai variabel intervening pada perusahaan sub sektor food and baverages di Bursa Efek Indonesia periode 2014 - 2019.

9. Diduga profitabilitas berpengaruh terhadap nilai pasar saham dengan share traded sebagai variabel intervening pada perusahaan sub sektor food and baverages di Bursa Efek Indonesia periode 2014 - 2019.

10. Diduga share traded berpengaruh terhadap nilai pasar saham perusahaan sub sektor food and baverages di Bursa Efek Indonesia periode 2014 - 2019.

\section{Metode Analisis Data}

Partial Least Square merupakan persamaan Structural Equation Modeling / SEM adalah suatu teknik statistik yang mampu menganalisis pola hubungan antara konstruk laten dan indikatornya, konstruk laten yang satu dengan lainnya, serta kesalahan pengukuran secara langsung. SEM memungkinkan dilakukannya analisis di antara beberapa variabel dependen dan independen secara langsung (Hair et al, 2009). SEM menjadi suatu teknik analisis yang lebih kuat karena mempertimbangkan pemodelan interaksi, nonlinearitas, variabel-variabel bebas yang berkorelasi (correlated independent), kesalahan pengukuran, gangguan kesalahan-kesalahan yang berkorelasi (correlated error terms), beberapa variabel bebas laten (multiple latent independent) dimana masing-masing diukur dengan menggunakan banyak indikator, dan satu atau dua variabel laten yang juga masing-masing diukur dengan beberapa indikator. Dengan demikian SEM dapat digunakan sebagai alternatif lain yang lebih kuat dibandingkan dengan menggunakan regresi berganda, analisis jalur, analisis faktor, analisis time series, dan analisis kovarian (Byrne, 2010).

Smart PLS mengasumsikan distribution free (tidak mengasumsikan data berdistribusi tertentu, dapat berupa kategori nominal, ordinal, interval dan rasio). Smart PLS dapat dianggap sebagai alternatif dari covariance based SEM dan lebih cocok untuk tujuan prediksi. Menurut Ghozali (2008), PLS dimaksudkan untuk causal-perdictive analysis dalam situasi kompleksitas yang tinggi dan dukungan teori yang rendah. Variabel laten (konstruk) dalam penelitian ini terdapat indikator-indikator yang bersifat reflektif, yaitu arah panah variabel laten (konstruk) menuju ke indikator, yang berarti mengasumsikan kontruk laten mempengaruhi variasi pengukuran dan asumsi hubungan kausalitas dari konstruk laten ke indikator. Ciri model indikator reflektif antaralain arah hubungan kausalitas dari variabel laten ke indikator, antar indikator diharapkan saling berkorelasi (memiliki internal consistency), menghilangkan satu indikator tidak akan menghilangkan makna dan arti variabel yang diukur, kesalahan pengukuran (error) pada tingkat indikator.

Adapun penelitian ini mengikuti langkah-langkah pengujian model penelitian berbasis PLS, (Yamin, 2011) sebagai berikut:

1. Merancang Model Struktural (inner model), pada tahap ini, peneliti memformulasikan model hubungan antar konstruk. Penelitian ini menggunakan 5 variabel yakni solvabilitas, aktifitas, profitabilitas, nilai pasar dan share traded dengan jumlah indikator penelitian sebanyak 16 indikator.

2. Merancang Model Struktural (outer model), pada tahap ini, peneliti mendefinisikan dan menspesifikasikan hubungan antar konstruk laten dengan indikatornya apakah bersifat reflektif atau formatif. Penelitian ini untuk menguji pengaruh solvabilitas, aktifitas dan profitabilitas terhadap nilai pasar saham dengan share traded sebagai variabel intervening pada perusahaan sub sektor food and baverages di Bursa Efek Indonesia.

3. Membuat diagram jalur, yang berfungsi untuk memvisualisasikan hubungan antar indikator dengan konstruknya serta antara konstruk yang akan mempermudah peneliti untuk melihat model secara keseluruhan. Hubungan antar konstruk seperti pada Gambar 1

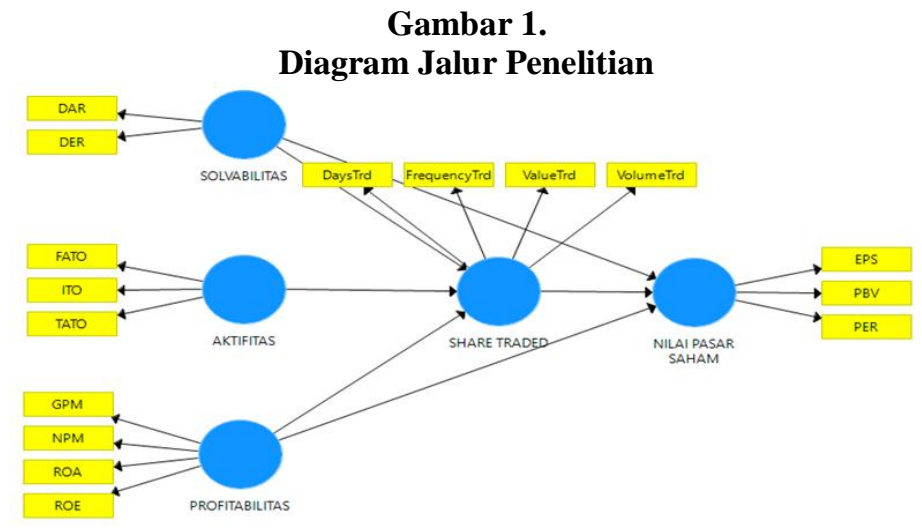


Siti Nur Ambarini dan Yunan Surono, Model Analisis Solvabilitas, Aktifitas dan Profitabilitas Terhadap Nilai Pasar Saham dengan Share Traded sebagai Variabel Intervening pada Perusahaan Sub Sektor Food And Baverages di Bursa Efek Indonesia Periode $2014-2019$

4. Uji kecocokan model pengukuran (fit test of measurement model) merupakan uji kecocokan pada outer model dengan melihat validitas konvergen (convergent validity) dan validitas diskriminan serta uji reliabilitas

5. Goodness of fit atau evaluasi model meliputi evaluasi model pengukuran dan evaluasi model struktural.

6. Pengujian hipotesis dan interpretasi

\section{Hasil}

Tabel 1

Nilai Construct Reliability and Validity PLS algorithm keenam

\begin{tabular}{|l|r|rr|r|}
\hline & Cronbach's Alpha & rho A & Composite Reliability & Average variance Extracted(AVE) \\
\hline Aktifitas & 0.602 & 0.717 & 0.788 & 0.562 \\
\hline Nilai Pasar Saham & 0.540 & 0.562 & 0.810 & 0.682 \\
\hline Profitabilitas & 0.702 & 1.134 & 0.794 & 0.572 \\
\hline Share traded & 0.555 & 0.534 & 0.755 & 0.522 \\
\hline Solvabilitas & 1.000 & 1.000 & 1.000 & 1.000 \\
\hline
\end{tabular}

Sumber : data olahan

Berdasarkan tabel 1. terlihat variabel aktifitas memiliki nilai Cronbach's Alpha sebesar 0,602 dalam kategori handal dan Average Variance Extracted memiliki nilai sebesar 0,562 dalam kategori valid dan variabel nilai pasar saham memiliki nilai Cronbach's Alpha sebesar 0,540 dalam kategori cukup handal yang berarti masih dapat diterima dan Average Variance Extracted memilik nilai sebesar 0,682 dalam kategori valid, variabel profitabilitas memiliki nilai Cronbach's Alpha sebesar 0,702 dalam kategori handal dan Average Variance Extracted memiliki nilai sebesar 0,572 dalam kategori valid, variabel share traded memiliki nilai Cronbach's Alpha sebesar 0,555 dalam kategori cukup handal yang berarti masih dapat diterima dan Average Variance Extracted memiliki nilai sebesar 0,522 dalam kategori valid, dan variabel solvabilitas memiliki nilai Cronbach's Alpha sebesar 1,000 dalam kategori handal dan Average Variance Extracted memiliki nilai sebesar 1,000 dalam kategori valid. Hasil calculate (perhitungan) PLS algorithm kelima dengan software Smart PLS 3.0 terlihat pada gambar 2

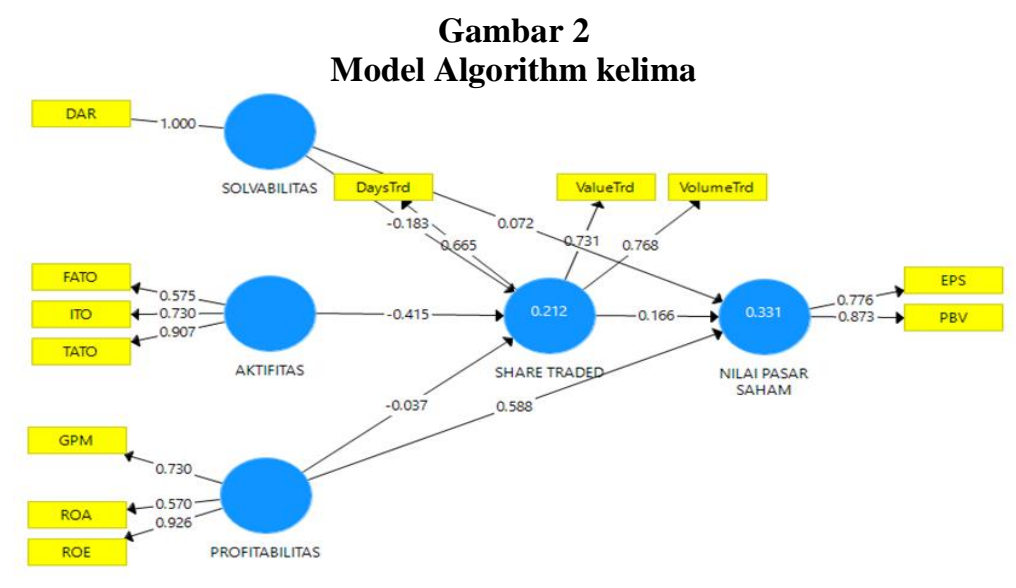

Berdasarkan gambar 2 dan tabel 2 terlihat, indikator yang mempunyai loading factor (outer loading) warna merah yakni indikator variabel aktifitas yang memiliki nilai loading factor terkecil (warna merah) yakni indikator FATO yakni sebesar 0,575 yang berarti belum ideal tapi masih dapat diterima. Indikator variabel profitabilitas yang memiliki nilai loading factor terkecil (warna merah) yakni indikator ROA yakni sebesar 0,570 yang berarti belum ideal tapi masih dapat diterima. Indikator variabel share traded yang memiliki nilai loading factor terkecil (warna merah) yakni indikator DaysTrd yakni sebesar 0,665 yang berarti belum ideal tapi masih dapat diterima. Yamin (2011) mengemukakan dalam penelitian pengembangan model atau indikator baru nilai loading factor antara 0,5 - 0,6 masih dapat diterima. Tabel 2 terlihat bahwa nilai Cronbach's Alpha (uji reliabilitas) belum memenuhi syarat, namun demikian masih dalam kategori cukup handal. Jika nilai Cronbach's Alpha mempunyai nilai yang lebih rendah maka dapat digunakan Composite Reability yang kesemuanya telah diatas 0,7. Siswoyo Haryono (2017), mengemukakan bahwa Composite Reability lebih baik dalam mengukur internal consistency dibandingkan dengan Cronbach's Alpha dalam SEM karena Composite Reability tidak mengasumsikan kesamaan boot dari setiap indikator. Average Variance Extracted (uji validitas), semua variabel telah memenuhi syarat yakni diatas 0,5., hal tersebut menggambarkan bahwa 
Siti Nur Ambarini dan Yunan Surono, Model Analisis Solvabilitas, Aktifitas dan Profitabilitas Terhadap Nilai Pasar Saham dengan Share Traded sebagai Variabel Intervening pada Perusahaan Sub Sektor Food And Baverages di Bursa Efek Indonesia Periode 2014 - 2019

uji validitas telah memenuhi syarat atau telah memiliki kelayakan data. Selain menggunakan AVE, uji validitas juga dapat menggunakan Validity Discriminant (validitas diskriminan) nilai cross loading lebih dari 0,7. Jogiyanto (2011).

Tabel 3 menunjukkan bahwa nilai cross loading Validity Discriminant masing-masing variabel diatas 0,7 yang tergolong baik, hal tersebut menggambarkan bahwa uji validitas telah memenuhi syarat atau telah memiliki kelayakan data. Langkah selanjutnya kita akan melihat besarnya Collinearity Statistic (VIF), yang akan memberikan gambaran tentang apakah data tersebut terjadi multikolinearitas atau tidak. Tabel 4 nilai inner loading VIF (inner VIF values) menunjukkan tidak terjadi multikolinearitas dimana pada variabel tersebut mempunyai nilai kurang dari 5 , warna hijau menunjukkan bahwa variabel tersebut adalah layak. Hasil perhitungan (calculate) dengan melakukan Bootstraping pada Smart PLS 3.0, diperoleh nilai koeffisien jalur (path coefficients) yang terdiri dari original sample $(\mathrm{O})$, sample mean $(\mathrm{M})$, standard deviation (STDEV), T statistics ([O/STDEV]) dan $\mathrm{P}$ values seperti pada tabel 5. Besarnya pengaruh antar variabel dapat diketahui dari kolom original sample dan untuk melihat tingkat signifikasi dapat diketahui dari kolom $T$ statistics. Menurut Ghozali (2006), nilai T Statistics yang berada diatas nilai 1,96 menunjukkan pengaruh yang signifikan dari masing-masing hipotesis. Besarnya pengaruh antar variabel dapat diketahui juga dari besarnya $\mathrm{P}$ values, jika nilai $\mathrm{P}$ values lebih kecil (kurang) dari 0,05 atau sebesar 5\% maka hubungan antar variabel tersebut dikatakan berpengaruh, demikian juga jika nilai $\mathrm{P}$ values lebih besar (diatas) 0,05 maka hubungan antar variabel dikatakan tidak berpengaruh.

Tabel 2

Nilai outer loading PLS algorithm kelima

\begin{tabular}{|c|c|c|c|c|c|}
\hline & Aktifitas & Nilai Pasar Saham & Profitabilitas & Share traded & Solvabilitas \\
\hline DAR & & & & & 1.000 \\
\hline DaysTrd & & & & 0.665 & \\
\hline EPS & & 0.776 & & & \\
\hline FATO & 0.575 & & & & \\
\hline GPM & & & 0.730 & & \\
\hline ITO & 0.730 & & & & \\
\hline PBV & & 0.873 & & & \\
\hline ROA & & & 0.570 & & \\
\hline ROE & & & 0.926 & & \\
\hline TATO & 0.907 & & & & \\
\hline ValueTrd & & & & 0.731 & \\
\hline VolumeTrd & & & & 0.768 & \\
\hline
\end{tabular}

Sumber : data olahan

Tabel 3

Nilai cross loading Validity Discriminant

\begin{tabular}{|l|r|r|r|r|r|}
\hline & \multicolumn{1}{|c|}{ Aktifitas } & Nilai Pasar Saham & Profitabilitas & \multicolumn{1}{c|}{ Share traded } & \multicolumn{1}{c|}{ Solvabilitas } \\
\hline Aktifitas & 0.750 & & & & \\
\hline Nilai Pasar Saham & 0.026 & 0.826 & & & \\
\hline Profitabilitas & 0.348 & 0.551 & 0.756 & & \\
\hline Share traded & -0.423 & 0.063 & -0.154 & 0.723 & \\
\hline Solvabilitas & -0.025 & -0.043 & -0.048 & -0.167 & 1.000 \\
\hline
\end{tabular}

Sumber : data olahan

Tabel 4

Nilai VIF (Variance Inflation Factors)

\begin{tabular}{|l|l|l|l|r|r|}
\hline & Aktifitas & Nilai Pasar Saham & Profitabilitas & Share traded & Solvabilitas \\
\hline Aktifitas & & & & 1.138 & \\
\hline Nilai Pasar Saham & & & & & \\
\hline Profitabilitas & & 1.058 & & 1.163 & \\
\hline Share traded & & $\mathbf{1 . 0 6 5}$ & & 1.023 & \\
\hline Solvabilitas & & $\mathbf{1 . 0 6 3}$ & & 1 \\
\hline
\end{tabular}

Sumber : data olahan 
Siti Nur Ambarini dan Yunan Surono, Model Analisis Solvabilitas, Aktifitas dan Profitabilitas Terhadap Nilai Pasar Saham dengan Share Traded sebagai Variabel Intervening pada Perusahaan Sub Sektor Food And Baverages di Bursa Efek Indonesia

Tabel 5

Nilai koeffisien jalur (path coefficients) hasil Bootstraping

\begin{tabular}{|c|c|c|c|c|c|}
\hline & Original Sample $(\mathrm{O})$ & Sample Mean (M) & Standard DeviatiOn (STDEV) & T Statistics ([O/STDEV]) & P Values \\
\hline Aktifitas -> Nilai Pasar Saham & -0.069 & -0.067 & 0.060 & 1.139 & 0.255 \\
\hline Aktifitas $->$ Share traded & -0.415 & -0.424 & 0.089 & 4.663 & 0.000 \\
\hline Profitabilitas -> Nilai Pasar Saham & 0.588 & 0.580 & 0.230 & 2.551 & 0.011 \\
\hline Profitabilitas $->$ Share traded & -0.037 & -0.053 & 0.170 & 0.217 & 0.828 \\
\hline Share traded $->$ Nilai Pasar Saham & 0.166 & 0.164 & 0.155 & 1.069 & 0.286 \\
\hline Solvabilitas -> Nilai Pasar Saham & 0.072 & 0.069 & 0.133 & 0.542 & 0.588 \\
\hline Solvabilitas $->$ Share traded & -0.183 & -0.180 & 0.108 & 1.693 & 0.091 \\
\hline
\end{tabular}

Sumber : data olahan

Hasil perhitungan path coeffisien berdasarkan tabel 5 tersebut menunjukkan bahwa;

- Variabel aktifitas tidak berpengaruh terhadap variabel nilai pasar saham karena nilai P values sebesar 0,255 atau sebesar 2,55\% sehingga lebih besar dari 0,05 atau sebesar 5\% maka hubungan antar variabel tersebut dikatakan tidak berpengaruh.

- Variabel aktifitas berpengaruh terhadap variabel share traded karena nilai P values sebesar 0,000 yakni lebih kecil (kurang) dari 0,05 atau sebesar 5\% maka hubungan antar variabel tersebut dikatakan berpengaruh

- Variabel profitabilitas berpengaruh terhadap variabel nilai pasar saham, karena nilai P values sebesar 0,011 atau sebesar $1,1 \%$ yakni lebih kecil (kurang) dari 0,05 atau sebesar 5\% maka hubungan antar variabel tersebut dikatakan berpengaruh

- Variabel profitabilitas tidak berpengaruh terhadap variabel share traded karena nilai $\mathrm{P}$ values sebesar 0,828 atau sebesar 8,28\% sehingga lebih besar dari 0,05 atau sebesar 5\% maka hubungan antar variabel tersebut dikatakan tidak berpengaruh.

- Variabel share traded tidak berpengaruh terhadap variabel nilai pasar saham karena nilai $\mathrm{P}$ values sebesar 0,286 atau sebesar 28,6\% sehingga lebih besar dari 0,05 atau sebesar 5\% maka hubungan antar variabel tersebut dikatakan tidak berpengaruh.

- Variabel solvabilitas tidak berpengaruh terhadap variabel nilai pasar saham karena nilai P values sebesar 0,588 atau sebesar 58,8\% sehingga lebih besar dari 0,05 atau sebesar 5\% maka hubungan antar variabel tersebut dikatakan tidak berpengaruh.

- Variabel solvabilitas tidak berpengaruh terhadap variabel share traded karena nilai $\mathrm{P}$ values sebesar 0,091 atau sebesar 9,1\% sehingga lebih besar dari 0,05 atau sebesar 5\% maka hubungan antar variabel tersebut dikatakan tidak berpengaruh.

Tabel 6

Nilai outer loading hasil Bootstraping

\begin{tabular}{|c|c|c|c|c|c|}
\hline & Original Sample $(\mathrm{O})$ & Sample Mean (M) & Standard DeviatiOn (STDEV) & T Statistics ([O/STDEV]) & P Values \\
\hline DAR $<-$ Solvabilitas & 1.000 & 1.000 & 0.000 & & \\
\hline DaysTrd <- Share traded & 0.665 & 0.642 & 0.158 & 4.128 & 0.000 \\
\hline EPS <- Nilai Pasar Saham & 0.776 & 0.637 & 0.368 & 2.108 & 0.033 \\
\hline FATO $<$ - Aktifitas & 0.575 & 0.578 & 0.119 & 4.832 & 0.000 \\
\hline GPM $<-$ Profitabilitas & 0.730 & 0.706 & 0.231 & 3.157 & 0.007 \\
\hline ITO $<$ - Aktifitas & 0.730 & 0.724 & 0.074 & 9.905 & 0.000 \\
\hline PBV <- Nilai Pasar Saham & 0.873 & 0.828 & 0.249 & 3.500 & 0.001 \\
\hline ROA $<-$ Profitabilitas & 0.570 & 0.574 & 0.215 & 2.654 & 0.008 \\
\hline ROE $<-$ Profitabilitas & 0.926 & 0.851 & 0.188 & 4.934 & 0.000 \\
\hline TATO <- Aktifitas & 0.907 & 0.903 & 0.027 & 33.531 & 0.000 \\
\hline ValueTrd <- Share traded & 0.731 & 0.717 & 0.123 & 5.940 & 0.000 \\
\hline VolumeTrd <- Share traded & 0.768 & 0.756 & 0.117 & 6.589 & 0.000 \\
\hline
\end{tabular}

Sumber : data olahan

Tabel 6 menampilkan nilai outer loading hasil Bootstraping, yang menggambarkan bahwa masing-masing indikator mempunyai pengaruh yang signifikan terhadap variabelnya, hal tersebut menggambarkan bahwa setiap indikator mampu merefleksikan dari variabel yang dibentuknya.

Hasil perhitungan path coeffisien berdasarkan tabel 7. tersebut menunjukkan bahwa;

- Variabel aktifitas tidak berpengaruh terhadap variabel nilai pasar saham dengan share traded sebagai variabel intervening, karena memiliki nilai $P$ values sebesar 0,255 atau sebesar 25,5\% sehingga lebih besar dari 0,05 atau sebesar 5\% maka hubungan antar variabel tersebut dikatakan tidak berpengaruh. 
- Variabel profitabilitas tidak berpengaruh terhadap variabel nilai pasar saham dengan share traded sebagai variabel intervening, karena memiliki nilai $P$ values sebesar 0,897 atau sebesar 89,7\% sehingga lebih besar dari 0,05 atau sebesar 5\% maka hubungan antar variabel tersebut dikatakan tidak berpengaruh.

- Variabel solvabilitas tidak berpengaruh terhadap variabel nilai pasar saham dengan share traded sebagai variabel intervening, karena memiliki nilai $\mathrm{P}$ values sebesar 0,500 atau sebesar 50,0\% sehingga lebih besar dari 0,05 atau sebesar 5\% maka hubungan antar variabel tersebut dikatakan tidak berpengaruh.

Gambar 3

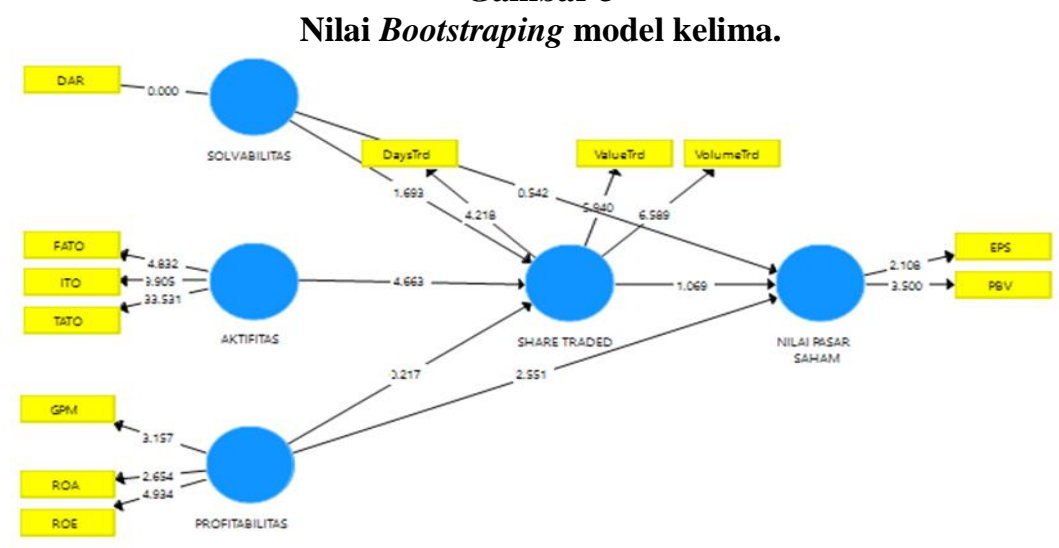

Tabel 7

Specific Indirect Effects hasil Bootstraping

\begin{tabular}{|c|c|c|c|c|c|}
\hline & Original Sample (O) & Sample Mean (M) & Standard DeviatiOn (STDEV) & T Statistics ([O/STDEV]) & P Values \\
\hline Aktifitas $->$ Share traded $->$ Nilai Pasar Saham & -0.069 & -0.067 & 0.060 & 1.139 & 0.255 \\
\hline Profitabilitas -> Share traded-> Nilai Pasar Saham & -0.006 & -0.017 & 0.047 & 0.129 & 0.897 \\
\hline Solvabilitas -> Share traded-> Nilai Pasar Saham & -0.030 & -0.036 & 0.045 & 0.675 & 0.500 \\
\hline
\end{tabular}

Sumber : data olahan

Hasil pengujian hipotesis dengan berdasarkan tabel 5 tersebut sabagai berikut:

1. Pengujian hipotesis pertama adalah diduga solvabilitas berpengaruh terhadap share traded perusahaan sub sektor food and baverages di Bursa Efek Indonesia periode 2014 - 2019. Pengujian hipotesis pertama variabel X1 yakni solvabilitas berpengaruh terhadap variabel I yakni share traded, karena mempunyai nilai P values sebesar 0,091 atau sebesar 9,1\%., dimana nilai $\mathrm{P}$ values tersebut lebih besar dari 0.05 atau lebih besar dari 5\% dan juga dapat dilihat pada nilai $\mathrm{T}$ statisik yakni sebesar 1,693 atau lebih kecil dari 1,96. Hal ini menunjukkan terdapat cukup bukti empiris untuk menolak hipotesis pertama. Dengan demikian disimpulkan bahwa variabel solvabilitas tidak berpengaruh terhadap variabel share traded.

2. Pengujian hipotesis kedua adalah diduga aktifitas berpengaruh terhadap share traded pada perusahaan sub sektor food and baverages di Bursa Efek Indonesia periode 2014 - 2019. Pengujian hipotesis kedua variabel X2 yakni aktifitas berpengaruh terhadap variabel I yakni share traded, karena mempunyai nilai P values sebesar 0,000 ., dimana nilai $\mathrm{P}$ values tersebut lebih kecil dari 0.05 atau lebih kecil dari $5 \%$ atau juga dapat dilihat pada nilai $\mathrm{T}$ statisik yakni sebesar 4,663 atau lebih besar dari 1,96. Hal ini menunjukkan terdapat cukup bukti empiris untuk menerima hipotesis kedua. Dengan demikian disimpulkan bahwa variabel aktifitas berpengaruh terhadap variabel share traded.

3. Pengujian hipotesis ketiga adalah diduga profitabilitas berpengaruh terhadap share traded pada perusahaan sub sektor food and baverages di Bursa Efek Indonesia periode 2014 - 2019. Pengujian hipotesis ketiga variabel X3 yakni profitabilitas berpengaruh terhadap variabel I yakni share traded, karena mempunyai nilai $\mathrm{P}$ values sebesar 0,828 atau sebesar 82,8\%., dimana nilai $P$ values tersebut lebih besar dari 0.05 atau lebih besar dari 5\% dan juga dapat dilihat pada nilai $\mathrm{T}$ statisik yakni sebesar 0,271 atau lebih kecil dari 1,96. Hal ini menunjukkan terdapat cukup bukti empiris untuk menolak hipotesis ketiga. Dengan demikian disimpulkan bahwa variabel profitabilitas tidak berpengaruh terhadap variabel share traded.

4. Pengujian hipotesis keempat adalah diduga solvabilitas berpengaruh terhadap nilai pasar saham perusahaan sub sektor food and baverages di Bursa Efek Indonesia periode 2014 - 2019. Pengujian hipotesis keempat variabel X1 yakni solvabilitas berpengaruh terhadap variabel $\mathrm{Y}$ yakni nilai pasar saham, karena mempunyai nilai $\mathrm{P}$ values sebesar 0,588 atau sebesar 58,8\%., dimana nilai $\mathrm{P}$ values tersebut lebih besar dari 0.05 atau lebih besar dari $5 \%$ dan juga dapat dilihat pada nilai $\mathrm{T}$ statisik yakni sebesar 0,542 atau lebih kecil dari 1,96. Hal ini menunjukkan 
Siti Nur Ambarini dan Yunan Surono, Model Analisis Solvabilitas, Aktifitas dan Profitabilitas Terhadap Nilai Pasar Saham dengan Share Traded sebagai Variabel Intervening pada Perusahaan Sub Sektor Food And Baverages di Bursa Efek Indonesia Periode $2014-2019$

terdapat cukup bukti empiris untuk menolak hipotesis keempat. Dengan demikian disimpulkan bahwa variabel solvabilitas tidak berpengaruh terhadap variabel nilai pasar saham.

5. Pengujian hipotesis kelima adalah diduga aktifitas berpengaruh terhadap nilai pasar saham perusahaan sub sektor food and baverages di Bursa Efek Indonesia periode 2014 - 2019. Pengujian hipotesis keempat variabel X2 yakni aktifitas berpengaruh terhadap variabel $\mathrm{Y}$ yakni nilai pasar saham, karena mempunyai nilai $\mathrm{P}$ values sebesar 0,255 atau sebesar 25,5\%., dimana nilai $\mathrm{P}$ values tersebut lebih besar dari 0.05 atau lebih besar dari $5 \%$ dan juga dapat dilihat pada nilai $\mathrm{T}$ statisik yakni sebesar 1,139 atau lebih kecil dari 1,96. Hal ini menunjukkan terdapat cukup bukti empiris untuk menolak hipotesis kelima. Dengan demikian disimpulkan bahwa variabel aktifitas tidak berpengaruh terhadap variabel nilai pasar saham.

6. Pengujian hipotesis keenam adalah diduga profitabilitas berpengaruh terhadap nilai pasar saham perusahaan sub sektor food and baverages di Bursa Efek Indonesia periode 2014 - 2019. Pengujian hipotesis keenam variabel X3 yakni profitabilitas berpengaruh terhadap variabel $\mathrm{Y}$ yakni nilai pasar saham, karena mempunyai nilai $\mathrm{P}$ values sebesar 0,011., dimana nilai $\mathrm{P}$ values tersebut lebih kecil dari 0.05 atau lebih kecil dari 5\% atau juga dapat dilihat pada nilai $\mathrm{T}$ statisik yakni sebesar 2,551 atau lebih besar dari 1,96. Hal ini menunjukkan terdapat cukup bukti empiris untuk menerima hipotesis keenam. Dengan demikian disimpulkan bahwa variabel profitabilitas berpengaruh terhadap variabel nilai pasar saham.

7. Pengujian hipotesis ketujuh adalah diduga solvabilitas berpengaruh terhadap nilai pasar saham dengan share traded sebagai variabel intervening pada perusahaan sub sektor food and baverages di Bursa Efek Indonesia periode 2014 - 2019. Pengujian hipotesis ketujuh variabel X1 yakni solvabilitas berpengaruh terhadap variabel Y yakni nilai pasar saham dengan variabel I yakni share traded sebagai variabel intervening, karena mempunyai nilai $\mathrm{P}$ values sebesar 0,500 atau sebesar 50,0\%., dimana nilai $\mathrm{P}$ values tersebut lebih besar dari 0.05 atau lebih besar dari 5\% atau juga dapat dilihat pada nilai T statisik yakni sebesar 0,675 atau lebih kecil dari 1,96. Hal ini menunjukkan terdapat cukup bukti empiris untuk menolak hipotesis ketujuh. Dengan demikian disimpulkan bahwa variabel solvabilitas tidak berpengaruh terhadap nilai pasar saham dengan share traded sebagai variabel intervening.

8. Pengujian hipotesis kedelapan adalah diduga aktifitas berpengaruh terhadap nilai pasar saham dengan share traded sebagai variabel intervening pada perusahaan sub sektor food and baverages di Bursa Efek Indonesia periode 2014 - 2019. Pengujian hipotesis kedelapan variabel X2 yakni aktifitas berpengaruh terhadap variabel Y yakni nilai pasar saham dengan variabel I yakni share traded sebagai variabel intervening, karena mempunyai nilai $P$ values sebesar 0,255 atau sebesar $25,5 \%$., dimana nilai $P$ values tersebut lebih besar dari 0.05 atau lebih besar dari $5 \%$ atau juga dapat dilihat pada nilai T statisik yakni sebesar 1,139 atau lebih kecil dari 1,96. Hal ini menunjukkan terdapat cukup bukti empiris untuk menolak hipotesis kedelapan. Dengan demikian disimpulkan bahwa variabel aktifitas tidak berpengaruh terhadap nilai pasar saham dengan share traded sebagai variabel intervening.

9. Pengujian hipotesis kesembilan adalah Diduga profitabilitas berpengaruh terhadap nilai pasar saham dengan share traded sebagai variabel intervening pada perusahaan sub sektor food and baverages di Bursa Efek Indonesia periode 2014 - 2019. Pengujian hipotesis kesembilan variabel X3 yakni profitabilitas berpengaruh terhadap variabel Y yakni nilai pasar saham dengan variabel I yakni share traded sebagai variabel intervening, karena mempunyai nilai $\mathrm{P}$ values sebesar 0,897 atau sebesar 89,7\%., dimana nilai $\mathrm{P}$ values tersebut lebih besar dari 0.05 atau lebih besar dari 5\% atau juga dapat dilihat pada nilai T statisik yakni sebesar 0,129 atau lebih kecil dari 1,96. Hal ini menunjukkan terdapat cukup bukti empiris untuk menolak hipotesis kesembilan. Dengan demikian disimpulkan bahwa variabel profitabilitas tidak berpengaruh terhadap nilai pasar saham dengan share traded sebagai variabel intervening.

10. Pengujian hipotesis kesepuluh adalah Diduga share traded berpengaruh terhadap nilai pasar saham perusahaan sub sektor food and baverages di Bursa Efek Indonesia periode 2014 - 2019. Pengujian hipotesis kesepuluh variabel I yakni aktifitas berpengaruh terhadap variabel $\mathrm{Y}$ yakni nilai pasar saham, karena mempunyai nilai $\mathrm{P}$ values sebesar 0,286 atau sebesar 28,6\%., dimana nilai $\mathrm{P}$ values tersebut lebih besar dari 0.05 atau lebih besar dari $5 \%$ dan juga dapat dilihat pada nilai $\mathrm{T}$ statisik yakni sebesar 1,069 atau lebih kecil dari 1,96. Hal ini menunjukkan terdapat cukup bukti empiris untuk menolak hipotesis kesepuluh. Dengan demikian disimpulkan bahwa variabel share traded tidak berpengaruh terhadap variabel nilai pasar saham.

\section{Pengujian kelayakan model (goodness of fit)}

Pengujian terhadap nilai $R$-square sebagai hasil uji goodness of fit model dilihat dari besaran angka nilai $R$ square, yang dapat dilihat di dalam tabel $R$-square dari hasil running calculate model pada variabel endogen share traded dan diperoleh angka sebesar 0,212 atau sebesar 21,2\%., pada variabel endogen nilai pasar saham dan diperoleh angka sebesar 0,331 atau sebesar 33,1\%. Angka tersebut memperlihatkan bahwa besarnya pengaruh keragaman data 
Siti Nur Ambarini dan Yunan Surono, Model Analisis Solvabilitas, Aktifitas dan Profitabilitas Terhadap Nilai Pasar Saham dengan Share Traded sebagai Variabel Intervening pada Perusahaan Sub Sektor Food And Baverages di Bursa Efek Indonesia Periode $2014-2019$

yang dapat dijelaskan oleh model tersebut adalah sebesar 33,1\%., sisanya sebesar 66,9\% dijelaskan oleh variabel lain yang belum terkandung dalam model tersebut dan termasuk error. Hasil tersebut memberikan makna bahwa model penelitian ini merupakan model yang tergolong moderat, menurut Chin (1998) dalam Ghozali seperti pada kriteria penilian PLS.

\section{Simpulan}

Kesimpulan penelitian ini sesuai dengan analisis penelitian yang telah dijelaskan pada bab sebelumnya yaitu:

1. Variabel solvabilitas tidak berpengaruh terhadap share traded pada perusahaan sub sektor food and baverages di Bursa Efek Indonesia periode 2014 - 2019.

2. Variabel aktifitas berpengaruh terhadap share traded pada perusahaan sub sektor food and baverages di Bursa Efek Indonesia periode 2014 - 2019.

3. Variabel profitabilitas tidak berpengaruh terhadap share traded pada perusahaan sub sektor food and baverages di Bursa Efek Indonesia periode 2014 - 2019.

4. Variabel solvabilitas tidak berpengaruh terhadap nilai pasar saham perusahaan sub sektor food and baverages di Bursa Efek Indonesia periode 2014 - 2019.

5. Variabel aktifitas tidak berpengaruh terhadap nilai pasar saham perusahaan sub sektor food and baverages di Bursa Efek Indonesia periode 2014 - 2019

6. Variabel profitabilitas berpengaruh terhadap nilai pasar saham perusahaan sub sektor food and baverages di Bursa Efek Indonesia periode 2014 - 2019.

7. Variabel solvabilitas tidak berpengaruh terhadap nilai pasar saham dengan share traded sebagai variabel intervening pada perusahaan sub sektor food and baverages di Bursa Efek Indonesia periode 2014 - 2019.

8. Variabel aktifitas tidak berpengaruh terhadap nilai pasar saham dengan share traded sebagai variabel intervening pada perusahaan sub sektor food and baverages di Bursa Efek Indonesia periode 2014 - 2019.

9. Variabel profitabilitas tidak berpengaruh terhadap nilai pasar saham dengan share traded sebagai variabel intervening pada perusahaan sub sektor food and baverages di Bursa Efek Indonesia periode 2014 - 2019.

10. Variabel share traded tidak berpengaruh terhadap nilai pasar saham perusahaan sub sektor food and baverages di Bursa Efek Indonesia periode 2014 - 2019

\section{Daftar Pustaka}

Abdullah, Faisal.M. (2004). Dasar-dasar Manajemen Keuangan. Penerbit Universitas Muhammadiah Malang, Malang.

Adipalguna, IGN Sudangga \& AAG Suarjaya., (2016), Pengaruh Likuiditas, Solvabilitas, Aktivitas, Profitabilitas Dan Penilaian Pasar Terhadap harga Saham Perusahaan LQ45 DI BEI. E-Jurnal Manajemen Unud, Vol. 5, No. 12, pp $7638-7668$.

Arifin, Bustanul et al, (2016), Pengaruh, Likuiditas, Solvabilitas, Profitabilitas, Nilai Pasar Dan Pemanfaatan Aset Terhadap Financial Statement Fraud. Tirtayasa Ekonomika, Vol. 11, No 2, pp 255 -279.

Arifin, Zaenal, (2005). Teori Keuangan dan Pasar Modal, Ekonosia, Yogyakarta,

Byrne, B. M. (2010). Multivariate applications series. Structural equation modeling with AMOS: Basic concepts, applications, and programming (2nd ed.). Routledge/Taylor \& Francis Group.

Dewi, Putu Eka Dianita Marvilianti., (2016), Pengaruh Rasio Likuiditas, Profitabilitas, Solvabilitas, Aktivitas dan Penilaian Pasar Terhadap Return Saham. Jurnal Ilmiah Akuntansi Vol. 1, No. 2, Hal: 109 - 132.

Fahmi, Irham. (2012).Analisis Kinerja Keuangan, Bandung: Alfabeta.

Fahmi, Irham. (2012), Manajemen Investasi, Jakarta: Salemba Empat

Fahmi, Irham. (2014). Pengantar Manajemen Keuangan, Bandung: Alfabeta.

Fahmi, Irham. (2017). Analisis Kinerja Keuangan. Bandung: Alfabeta.

Ferdinand, Augusty (2006). Metode Penelitian Manajemen: Pedoman Penelitian untuk skripsi, Tesis dan Disertai Ilmu Manajemen. Semarang: Universitas Diponegoro.

Ghozali, Imam. (2001). Pokok-pokok Analisis Laporan Keuangan. Yogyakarta: BPFE.

Ghozali Imam. (2009). Aplikasi Analisis Multivariate dengan Program SPSS. Penerbit: Universitas Dipenogoro. Semarang,

Ghozali, Imam. (2013). Aplikasi Analisis Multivariate dengan Program IBM SPSS 21 Update PLS Regresi. Semarang: Badan Penerbit Universitas Diponegoro.

Hair et.al. (2009), Multivariate Data Analysis 5th ed., Englewood Cliffs, NJ: PrenticeHall Int'1.

Hartono, Agus. (2010). Manajemen Keuangan. Edisi keempat. Yogyakarta : BPFE.

Hanafi, Mamduh dan Abdul Halim, (2012), Analisis Laporan Keuangan. Yogyakarta: (UPP) STIM YKPN.

Hasan, Iqbal, (2009), Analisis Data Penelitian Dengan Statistik, Bumi Aksara, Jakata. 
Husnan, Suad, (1998), Manajemen Keuangan: Teori dan Penerapan : Edisi Ke enam, BPFE, Yogyakarta.

Husnan, Suad. (2014), Dasar-Dasar Manajemen Keuangan, unit Penerbit dan Pencetakan (UPP)-AMP ,YKPN, Yogyakarta.

Jogiyanto, (2010), Analisis Investasi dan Teori Portofolio, Gajah Mada Press, Yogyakarta.

Jumingan, (2009), Analisis Laporan Keungan, Bumi Aksara, Jakarta.

Kamaludin, dan Rini Indriani. (2012). Manajemen keuangan. Edisi Revisi. CV. Bandar Maju. Bandung.

Kasmir, (2009). Pengantar Manajemen Keuangan Edisi Kedua, Jakarta : Kencana Prenada Media Group.

Kasmir, Jakfar. (2008), Analisis Laporan Keuangan, PT Rajagrafindo Persada, Jakarta.

Kasmir, (2014), Analisis Laporan Keuangan, Edisi Satu. Cetakan ketujuh. Jakarta: PT Raja Grafindo Perkasa.

Kasmir. (2015). Analisis Laporan Keuangan. Jakarta: Rajawali Pers.

Lumbantobing, Rudolf.,(2016), Efek Rasio, Likuiditas, Rasio Profitabilitas, Solvabilitas Dan Rasio Aktivitas Pada

Harga Saham Yang Dimediasi Oleh Rasio Solvabilitas Perusahaan Sub Sektor Industri Perkebunan Yang

Tercatat Di Bursa Efek Indonesia. Jurnal Ilmiah Manajemen Bisnis, Vol. 16, No. 2, Juli - Desember, pp 81 99.

Martono dan Harjito (2010)., Manajemen Keuangan, Yogyakarta, Ekonisia.

Munawir. S, (2007), Analisa Laporan Keuangan, Yogyakarta: Liberty.

Prastowo dan Julianty, (2002), Analisis Laporan Keuangan : Konsep dan Manfaat. Yogayakarta : AMP-YKPN

Prihadi, Toto. (2011). Analisis Laporan Keuangan Teori dan Aplikasi Jakarta: PPM

Priyanto (2013). Mandiri Belajar Analisis Data dengan SPSS. Yogyakarta. Mediakom

Raharja Putra, Hendra S, (2011). Buku Panduan Praktis Manajemen Keuangan dan Akuntansi untuk Eksekutif Perusahaan, Cetakan Pertama. Salemba Empat. Jakarta.

Rosyana, Deajeng. (2018), Pengaruh , Likuiditas, Aktivitas, Solvabilitas, Profitabilitas Terhadap Perubahan Laba Perusahaan Retail Trade DI BEI., Jurnal Ilmu dan Riset Manajemen, pp 1 - 16.

Sarwanto, Wandi \& Kardinal., (2014), Analisis Pengaruh Profitabilitas, Likuiditas, Solvabilitas, Total Asset Turnover (TATO) Terhadap Nilai Perusahaan Pada Perusahaan Manufaktur Yang Terdaftar Di Bursa Efek Indonesia Periode 2013-2017. Jurnal STIE Multi Data Palembang.

Silviyani. (2014). Pengaruh Likuiditas Perdagangan Saham dan Kapitalisasi Pasar Terhadap Return Saham Perusahaan Yang Berada Pada Indeks LQ45 Di Bursa Efek Indonesia Periode Tahun 2009-2013 (Studi Empiris PadaPerusahaan Lq45 Di Bursa Efek Indonesia). e-Journal S1 Ak Universitas Pendidikan Ganesha Jurusan Akuntansi SI.(Volume: 2 No. 1.)

Sudana, I Made. (2011). Manajemen Keuangan Perusahaan Teori dan Praktik, ERLANGGA, Surabaya.

Sudana. I Made. (2015). Manajemen Keuangan Perusahaan, edisi dua. Jakarta. Erlangga.

Sugiyono. (2010). Metode Penelitian Kuantitatif, Kualitatif dan R\&D. Penerbit Alfabeta, Bandung.

Sugiyono, (2013). Metode Penelitian Manajemen. Penerbit: Afabeta, Bandung.

Trirahayu L, Justina,.(2015), Pengaruh Rasio , Likuiditas, Solvabilitas, Aktivitas, Profitabilitas Dan Produk domestic Bruto Terhadap Pertumbuhan Laba Pada Perusahaan Tekstil Dan Garmen Yang Terdaftar DI BEI. JRKA Volume 1 Isue 2, Agustus pp: 60 - 70.

Zubir, Zalmi. (2011), Manajemen Portofolio: Penerapannya dalam Investasi Saham. Salemba Empat: Jakarta.. 